ISPEC Tarım Bilimleri Dergisi

$2020: 4(3)$

(C) Telif hakk ISPEC'e aittir

Arasturma Makalesi

*Şüheda Basire AKÇA

Orcid No: 0000-0001-9390-1921

**Funda ÜNAL ANKAYA

Orcid No: 0000-0002-8305-1131

*Zonguldak Bülent Ecevit

Üniversitesi/Çaycuma Gıda ve Tarım

Meslek Yüksekokulu (Sorumlu yazar)

**Celal Bayar Üniversitesi, Alaşehir

Meslek Yüksekokulu

fundaunalankaya@hotmail.com

DOI

https://doi.org/10.46291/ISPECJASv ol4iss3pp565-580

Geliş Tarihi: 16/07/2020

Kabul Tarihi: 25/08/2020

\footnotetext{
Anahtar Kelimeler

Peyzaj öğeleri, donatı öğeleri, kent kimliği, Yeşilırmak, rekreasyonel alan

Keywords

Landscape elements, equment elements, urban identity
}

www.ispecjournal.com

\section{Rekreasyonel Alanlarda Kullanılan Donatı Elemanlarında Kullanıcı Memnuniyetinin Belirlenmesi; Tokat Yeşilırmak Çevresi Örneği}

\section{Özet}

$\mathrm{Bu}$ çalışmada, Tokat ili halkının en sık kullandığı Yeşilırmak çevresinde bulunan rekreasyon alanlarındaki donatı elemanları ile ilgili olarak kullanıcı memnuniyetinin belirlenmesi amaçlanmıştır. Memnuniyet/ memnuniyetsizlik durumlarını belirlemek adına yöntem olarak anket çalışması tercih edilmiştir. 2019 yılında yapılan çalışma, Basit tesadüfi örnekleme yöntemine göre 384 rekreasyon alanı kullanıcısının donatı elemanları açısından memnuniyeti, \% 5 hata payı ve\% 95 güvenirlik ile belirlenmiştir. Kullanıcıların demografik yapısının yanı sıra 20 rekreasyon alanını doğru yansıtacak güçlendirme unsurları için ulaşım ve güçlendirme unsurları sorulmuştur. Likert ölçeğine göre puanlanan soruların puantaj değerlendirmesi, puanların ortalaması alınarak gerçekleştirilmiştir. Çalışma, kullanıcıların memnuniyet düzeyini azaltan unsurların nasıl ortadan kaldırılabileceği ve bunun yanı sıra memnuniyet düzeyini artırmak ve devamlılığını sağlamak açısından önemlidir.

\section{The Determination User Satisfaction of Equipment Elements In The Recreational Area of The Yesilırmak Environs /Tokat City}

\section{Abstract}

In this study, it was aimed to determine the user satisfaction to reinforcement elements of the in recreational areas located in the environs of Yeşilırmak, where is used most frequently by Tokat city people. In order to determine the satisfaction / dissatisfaction situations, a survey study was preferred as a method. The study carried out in 2019. According to the simple random sampling method, the satisfaction of the 384 recreational area users in terms of reinforcement elements was determined with $5 \%$ margin of error and $95 \%$ reliability. Besides the demographic structure of the users, transportation and reinforcement elements were asked about reinforcement elements that would reflect 20 recreational areas correctly. The average of the questions scored according to the Likert scale was evaluated. It was important in terms of how to eliminate the factors that reduce the satisfaction level of the users, as well as increasing the level of satisfaction and ensuring its continuity. 


\section{GíRIŞ}

Kentler, oluştuğu günden beri doğal ve kültürel öğelerle varolmuştur ve şekil değiştirmiştir (Güneş ve ark., 2005; Gülgün ve ark., 2014; Akça ve ark., 2019; Gülgün Yazici, 2018). Tarihi ve teknolojik gelişmeler, kentlerde hızlı hazırlıksız ve dramatik bir şekilde ilerlemiş, bu da kentlerin yatay ve dikey yönde gelişmesine sebep olmuştur. Özellikle bu gelişmeler sonucunda kentler, insan yapısı veya ergonomisi ile bağdaşmayan, soğuk, kullanıcı gereksinimlerini karşılamaktan yoksun, görsel açıdan yetersiz bir çevre halini almaktadır. Kentleri sadece barınma alanları olarak nitelendirmemek gerekir. Çubuk (1991)'in belirtiği gibi; kentler, yerleşme dokusunu oluşturan yapılanmış ve /veya yapılanmamış 'Kentsel Mekânları' oluşturmaktadır. Kentler, barınmanın yanı sıra çalışma, eğlenme/dinlenme ve ulaşım gibi dört ana işleve sahiptir. Kentlerin dış mekânları, insanlar için huzurlu, güvenli ve kolaylık verici düzenlenmelidir. Özellikle insanların nefes almaları açısından oluşturulan yeşil alan sistemleri içinde donatı elemanları, önemli yere sahiptir.
Donatı elemanları, insanların kent dokusu içinde bireysel ve toplumsal yaşamını kolaylaştıran, bireylerin iletişim halinde olduğu mekanlara işlevsel ve estetik açıdan anlam kazandıran, kısaca değişik nitel ve nicelikleri olan mekan tamamlayıc1 öğeler/objelerdir (Bulut ve ark., 2008; Güneş ve ark., 2011; Önal, 2019; Gülgün ve ark., 2018). Donatı elemanları, kullanıcıların sosyal ve kültürel özelliklerini yansıtacak şekilde nesnelerden beklentileri, görsel estetik değer yargılarını içinde barından çevre düzenlenmesini gerektirmektedir. Kent kimliğine dayanan ve onun önemli bir parçası olan donatı elemanlarının, teknik ve görsel açıdan devamlılığı sağlanmalıdır. Bayrakçı (1991) yaptığı çalışmada, donatı elamanlarının kent dokusu içinde insanların hayatını kolaylaştırdığını, bireyler arasında iletişıme olumlu katkı sağladığını, işlevsel ve estetik açıdan kent kimliğine katkılar sunduğunu, mekân tamamlayıcı bir öğe olduğunu bildirmiştir. Kuşkun (2002)'e göre donatı elemanları şu şekilde sınıflandırılabilir (Şekil 1). 


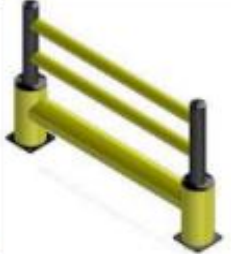

Sınırlandırıcılar (caydırıcılar, sınırlandırıcılar, yaya bariyerleri, trafik bariyerleri, vb.)

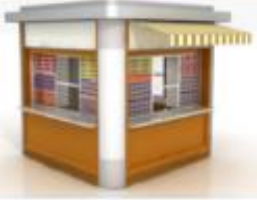

Satış birimleri (kiosklar, sergi pavyonları, büfeler, vb.)
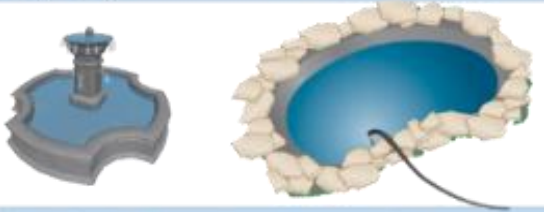

Su öğesi (süs havuzları, çeşmeler tulumbalar, kanallar, yangın musluğu, vb.)
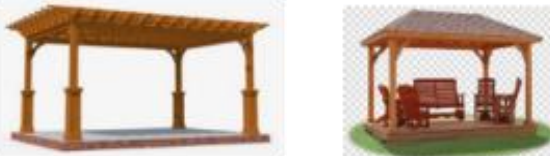

Üst örtü öğeleri (duraklar, gölgelikler, pergolalar, vb.)
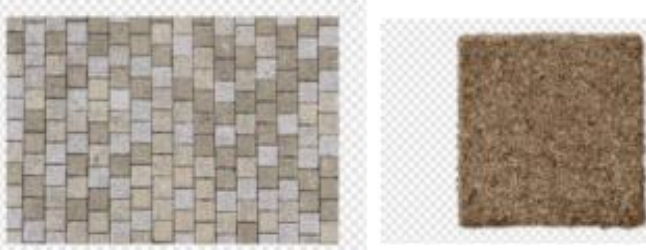

Zemin kaplamaları (beton, taş, asfalt, tuğla, vb.)
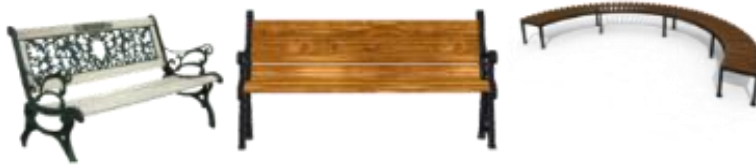

Oturma birimleri (banklar, sandalyeler, gurup oturma elemanları)
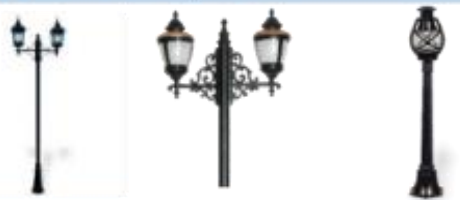

Aydınlatma elemanları (yol aydınlatıcıları, alan aydınlatıcıları)
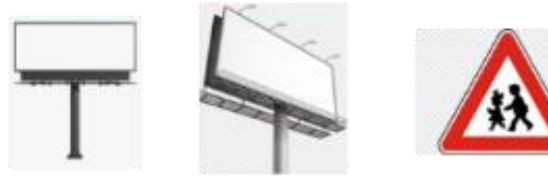

Işaret ve bilgi levhaları (yönlendiriciler, yer belirleyiciler, bilgi iletişim panoları)
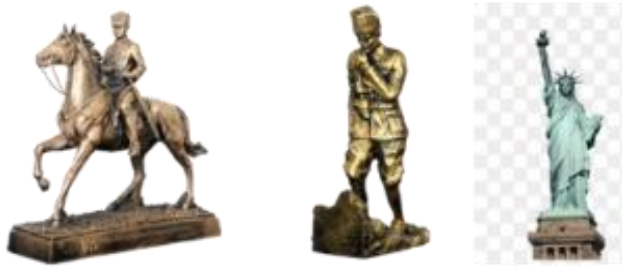

Sanatsal objeler (heykeller)
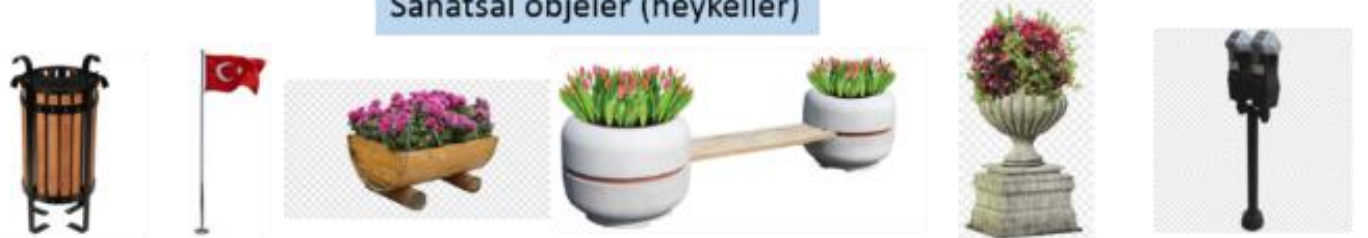

Diğer öğeler (bayrak direkleri, çöp kutuları, posta kutuları, umumi tuvaletler, çiçeklikler, bilet otomatları, bisiklet park yerleri, saatler, parkmetreler, bitkisel öğeler, vb.)

Şekil 1. Donatı elamanları sınıflamasına göre kentsel alanlarda kullanılan öğeler 
İnsan boyutlarının ve buna bağlı olarak yatay ve dikey çalışma alanlarının saptanması, araç-gereç donatım-döşeme boyutlarının ve kalitesinin belirlenmesi, aktivite mekânlarının ve boyutlarının insan kullanımına uygunluğunun saptanması gerekir. Buradan çıkan verilere ve eksiklere göre, mekânların tasarımında kullanılacak verilerin standart şekilde var olmadığının gösterilmesi ve bunların, gerek mobilya, gerekse donatım-döşeme elemanlarının tasarımında ortaya konması gerekir (Gülgün ve Türkyılmaz, 2001a; Gülgün ve Türkyılmaz, 2001b; Gülgün ve Yazici, 2017). Donatı elemanları, çevre düzenlemesi içinde kentlerde yaşam tarzı anlayışı boyutunda kültürel de boyut kazanmaktadır. Bu nedenle yapılan birçok çalışmada donatı elemanları, incelenen yerin kültürel kimliğini yansıtmaktadır. Bayramoğlu ve Özdemir (2012) Trabzon Merkezinde yer alan Uzun Sokak'ta donatı elemanlarını inceleyerek, mevcut donatı elemanlarının cadde üzerinde bir bütünlük oluşturmadığ 1 ve çevresindeki mimari yapı ile de uyum sağlamadığını tespit etmişlerdir. Uzun Sokak üzerinde bulunan donatı elemanlarının Trabzon kent kimliğini yansıtmadığı, kent kimliğini vurgulamak adına herhangi bir özelliğe sahip olmadığı sonucuna varılmıştır. Önal
(2009), Yörük (2006); Yazici ve ark., 2018; Yazici ve Gülgün, 2017; Akça ve ark., 2018, gibi birçok çalışmada belirtildiği gibi, donatı elamanları ile ilgili yapılacak olan çok disiplinli çeşitli araştırmalar ile, donatı elemanlarının tasarımında kullanılacak olan antropometrik veri tabanının oluşturulması son derece önemlidir. K1saca donatı elemanlarının, yüklendikleri işlevsel görevlerin yanı sıra kentsel alan içindeki anlamsal boyutları da değerlendirildiğinde, kentler için önemli simgeler olduğu ortaya çıkmaktadır. Bu çalışmada 2019 yılında tekrar yenilenen Tokat Yeşilırmak kenarındaki donatı elemanlarının, kullanıcılar tarafından değerlendirilmesi yapılmıştır. İnsanların boş zamanlarını geçirdiği bu alanlar, bulunduğu konum itibariyle kent kimliğini yansıtması gereken alanlardan bir tanesidir. Yazici ve Arslantaş (2019) çalışmasının devamı niteliğinde olan bu çalışmada, donatı elamanları ile kent kimliği arasındaki uyum ve yeterlilik, anket yoluyla belirlenmiştir. Çalışmada amaç; donatı elemanları ile ilgili memnuniyetin ve kent kimliğine uygun olup olmadığının belirlenmesinin yanısıra, elde edilen veriler ışı̆̆ında ve seçim kararlarına ilişkin problemlerin de belirlenerek soruna dair çözüm önerileri geliştirmektir. 


\section{MATERYAL -YÖNTEM}

Anketin yapıldı̆̆ 1 Tokat ili; Türkiye'nin Karadeniz Bölgesinde yer alan illerden biridir. Kuzeyde Samsun, kuzeydoğuda Ordu, doğu ve güneyde Sivas, güneybatıda Yozgat ve batıda Amasya illeriyle Komşudur. İlçelerinden Yeşilyurt ve Sulusaray, İç Anadolu Bölgesinde yer alır. Yüzölçümü 10.072 km², Nüfusu 612.646 olup rakımı 623 m'dir. Y1llı sicaklık ortalaması en düşük $8.1^{\circ} \mathrm{C}$, en fazla 14.2 ${ }^{\circ} \mathrm{C}$ 'dir. Yıılık yağış ortalaması $381.7 \mathrm{~mm}$ ile $586.2 \mathrm{~mm}$ arası değişmektedir. Tokat; Yeşilırmak havzasının bereketli toprakları üzerine kurulmuş 6000 y1llık tarihi boyunca önemli ticaret ve kültür merkezi olmuş, 14 Devleti ve birçok beyliği içerisinde barındırmış önemli bir Anadolu şehridir (Erişim: Tokat Belediyesi, 2019; Yazici ve Arslantaş, 2019).

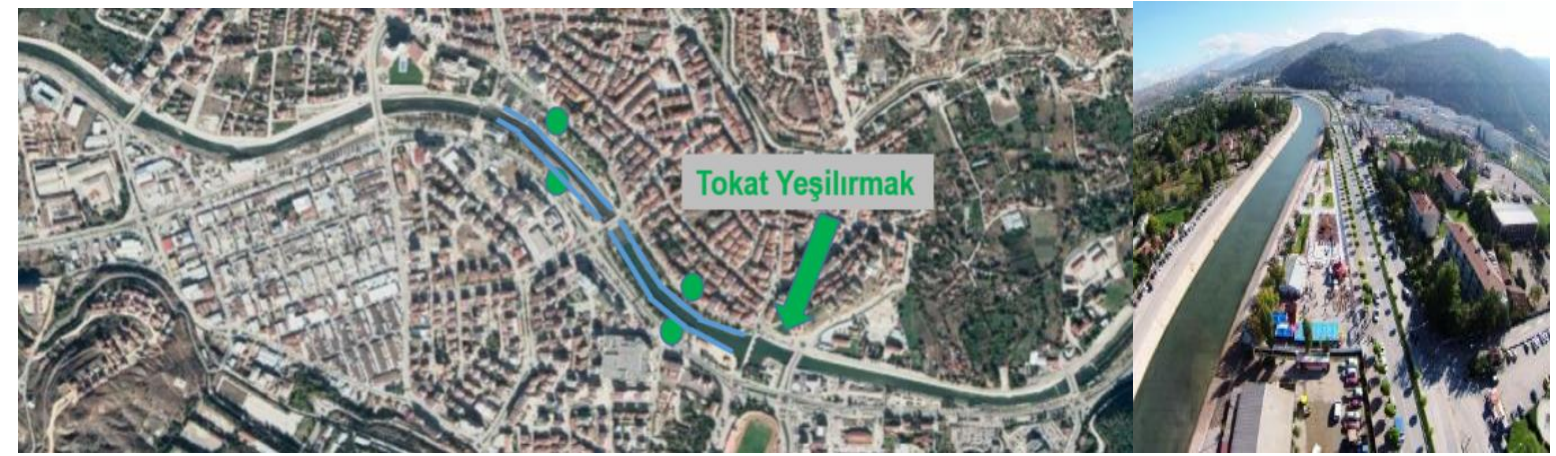

Şekil 2. Tokat Yeşilırmak kenarına ait çalışma alanının, uydu görüntüsü ve havadan çekilmiş fotoğrafı (Tokat Bel., 2019).

Çalışmanın ana materyalini; Tokat ilinin Yeşilırmak yakın çevresi oluşturmaktadır. Tokat halkının tercih ettiği bu alan; (Tarihi Taşhan'dan Yaklaşık 3,5 km uzaklıkta) ulaşım açısından kolay olması, su öğelerinin varlığg ile günün her saatin de rekreasyonel olarak yararlanılabilen bir ortamdır. Vali Zekai Gümüşdiş Bulvarı boyunca devam eden rekreasyonel alan Tarihi Taş köprüden başlayarak Sanayi kavşağı yol ayrımında son bulmaktadır. Irmak kenarının diğer yakası ise Karşıyaka mahallesini kapsamaktadır. Yürüyüş yolları, bisiklet yolları, çocuk oyun parklarının bulunması, spor kompleksinin olması, 1rmakta gondol gezintilerinin yapılması ve insanların piknik amaçlı kullanabilecekleri kameriye bulunması, ayrıca çay bahçelerini de içinde barındırması ile halkın tercih ettiği bir rekreasyon alanıdır. Yeşilırmak kenarının şehir merkezine yakınlığı, insanların bir vasıta olmadan da gidebileceği, her yaş grubundan insanların kolay ulaşabileceği 


\section{ISPEC Tartm Bilimleri Dergisi \\ $2020: 4(3)$ \\ (C) Telif hakk ISPEC'e aittir}

Arastırma Makalesi
E-ISSN:2717-7238

: $\mid$ SPECG

www.ispecjournal.com
ISPEC Journal of Agr. Sciences

$2020: 4(3)$

Copyright $(\mathrm{C}$ ISPEC

$\underline{\text { Research Article }}$

bir rekreasyonel alan kazanımı

Tokat ili Merkez ilçesinde donatı elemanı

sağlamaktadır. Ayrıca Yeşilırmak yakın kullanıcı memnuniyetleri değerlendirmeyi çevresi; etrafinda bulunan Taş Köprüsü, Yeşilırmak Bilgi Evi ve Millet kıraathanesi gibi tarihi mekânlar ile insanların sosyal yaşamını olumlu yönde etkilemesinin yanı sıra bilgi birikimlerinin artmasına olanak sağlayan bir alandır (Şekil 2).

amaçlayan bu çalışmada; Yeşilırmak kenarında bulunan parklar örnekleme alanı olarak seçilmiştir. Yapılan 384 kişilik anket çalışması, SPSS (PC) paket programı kullanılarak İstatiksel analiz teknikleriyle değerlendirilmiştir. Çalışma 5 aşamada tamamlanmıştır (Şekil 3).

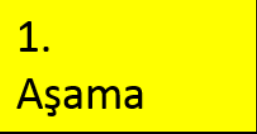

Çalışma konusu ile ilgili web tabanlı kaynak taraması yapılmıştır.

2.

Aşama

3.

Aşama

4.

Aşama

5.

Aşama
Yeşilırmak kenarındaki rekreasyonel alanlarda donatı elemanlarının mevcut durumu göz önünde bulundurularak donatı elamanlarının özellikleri gruplandırılmıştır.
Anket soru formu oluşturulmuştur.

Yeşilırmak kenarında rekreasyonel alan kullanıcılarına 384 kişilik anket yapılmıştır.

Anket sonuçları değerlendirilerek çalışma tamamlanmıştır.

Şekil 3. Yöntem akış şeması
Anket çalışmasında ve Anket formlarının oluşturulmasında, Aksu ve Yılmaz (2018) ve Düzenli ve ark. (2017) ve Yazici ve Arslantaş Sağlamer (2019) gibi bugüne kadar yapılmış olan çeşitli araştırmalardan yararlanılmıştır.

Örnekleme modeli olarak; basit tesadüfi örnekleme yöntemine göre örnekleme 
hacmi $\% 5$ hata payı ve $\% 95$ güvenilirlikte çalışılmıştır.Örneklem büyüklükleri hesaplanırken Yazıcıoğlu ve Erdoğan (2004)'dan yararlanılmıştır. Ocak- Mayıs ayları arasında 2019 tarihinde, hafta içi ve hafta sonları, yanıt verecek kişiler rastgele

Formül $\mathrm{n}=\mathrm{Nt}^{2} \mathrm{pq}$ seçilerek yapılmıştır. Anket, kişisel görüşme ile yürütülmüş, Tokat Yeşilırmak kenarında bulunan rekreasyonel alanlardaki donatı elamanlarını kullanan kullanıcılar üzerinde yürütülen toplam 384 adet anket formunun doldurulması ile elde edilmiştir.

\section{n:Örnek hacmi}

$\mathrm{N}$ : Toplam Tokat Merkez nüfusu

p: Gerçekleşme sıklığı

q: Gerçekleşmeme sıklığı

t: Belirli bir anlamlılık düzeyi (1.96)

Verilerin değerlendirilmesi, Demografik yapı ve kullanım zamanı soruları dışında kalan tüm anket soruları (20 soru) 5'li Likert ölçeği ile değerlendirilmiştir. Aksu ve Yılmaz (2018) ve Yazici ve Arslantaş Sağlamer (2019)'e göre elde edilen puanlama sonrası standart sapma, ortalama değer, anketlerin aralık sınırlarının hesaplanması, aralık katsayı hesaplamasıyla hesaplanmış ve 0.60 , ortalama ile karşılaştırmalar esas olmak üzere değerlendirme yapılmıştır. Araştırma verilerinin analizinde frekans, yüzde, ortalama ve standart sapma gibi tanımlayıcı istatistiklerden yararlanılmış ve IBM SPSS 22.0 programı kullanılmıştır.

\section{BULGULAR}

\section{Demografik özellikler}

384 kişiye yapılan anket sonucunda; ankete katılan katılımcıların \%51,3 (197 kişi) kadın \%48,7(187 kişi) erkektir. Ankete katılanların \%93 ü kent merkezinde yaşıyorken \%7'si kent dışından gelmiş olan ziyaretçilerden oluşmaktadır. Ankete katılanların büyük çoğunluğu16-29 yaş (175 kişi) ve 30-45 yaş (143 kişi) olup, 46-60 yaş grubundan 52 kişi ve en az 60 yaş üzeri (14kişi) olarak belirlenmiştir. Ankete katılan katılımcıların eğitim durumu sonucuna göre en fazla sayı 190 kişi ile üniversite mezunu olanlar olmuş, 102 kişi lise, 57 kişi ilköğretim olmuş ve en az ise 35 kişi ile lisansüstü eğitime sahip olanlar katılmıştır.

\section{Rekreasyonel alanı ziyaret etme zamanı}

384 kişiye yapılan anket sonucunda katılımcıların \%21,6'sı hafta içi \% 72,7 si hafta sonu,\%5,7 si isehem hafta sonu hem hafta içi çalışma alanını kullanmaktadır. Kullanıcıların \%52,3 akşam vakileri \%31,3 ü öğle ve \%9,4 öğle ve akşam vakitlerinde ziyaret etmektedir. 


\section{Donatı elemanlarına ait memnuniyeti belirlenmesi}

Anket sonuçlarına göre; ilk olarak 'Yeşilırmak kenarında yürüyüş yolu yeterlidir' görüşüne katılma oranı ortalaması 0,85 (Ort. üstünde) puan olarak belirlenmiştir. Bu sonuç, kullanıcıların alana ulaşımda sorun yaşamadıklarını göstermektedir. İkinci soru olan 'Yeşilırmak kenarında yürüyüş yolu tüm kullanıcılar engelliler/çocuk/yaşlı için uygundur' görüşüne katılım oranı 0,62 (Ort. üstünde) olarak belirlenmiştir. Üçüncü soruya verilen 'Yeşilırmak kenarındaki yeşil alanı sınırlayan elemanlar yeterlidir' görüşüne katılanların ortalaması 0,30 (düşük) olarak belirlenmiştir. Dördüncü soruda ise; 'Yeşilırmak kenarında çardak ve örtü elemanı yeterlidir' görüşüne katılanların ortalaması 0,47 (düşük) olarak belirlenmiştir. Elde edilen sonuçlar göz önünde bulundurulduğunda; rekreasyon alanındaki yürüyüş yolları yeterli bulunurken, sınırlayıcı elemanlar yeterli bulunmamıştır. Ayrıca yine yapılan anket sonucunda, çardak ve üstü örtülü elamanların yetersiz olduğu sonucu ortaya çıkmıştır (Tablo 1). Ankette beşinci başlık olan aydınlatma elemanı ile ilgili olarak ; 'Yeşilırmak kenarında aydınlatma elemanı yeterlidir'görüşünde olanların katılım oranı 0,78 (Ort. üstünde) olarak belirlenmiştir. Altıncı soruya 'Yeşilırmak kenarında gölgeleme elemanı (bitki fonksiyonu ele alınarak) yeterlidir' görüşüne katılım oranı 0,83 (Ort. üstünde) olarak ortaya çıkmıştır. Yedinci soruda ise; Yeşilırmak kenarında zemin kaplaması yöre için uygundur görüşüne katılanlarının ortalaması 0,61 (ortalama değer) olarak belirlenmiştir. sekizinci Soru 'Yeşilırmak kenarında plastik nesneler mevcuttur’ görüşünün ortalaması 0,46 (düşük) olarak belirlenmiştir. Dokuzuncu soru olan 'Yeşilırmak kenarında yeterli sayıda çöp kutusu mevcuttur' görüşünde verilen puan 0,63 olarak belirlenmiştir. Onuncu Soruda ise 'Yeşilırmak kenarında su öğesine yer verilmiştir' görüşü,0,82 puan almıştır. Bu sonuçlardan elde edilen verilere göre; aydınlatma elemanları, alandaki bitkilerin gölgeleme fonksiyonu, su öğesi kullanımı ortalamanın üstünde puan almıştır. Kullanıcılar, aydınlatma elemanları, alandaki bitkilerin gölgeleme fonksiyonu, su öğelerinden memnun iken çöp kutusu kullanımı ortalama değer skalasında kalmıştır (Çizelge $1)$. 
Çizelge 1. Donatı elemanlarına ait memnuniyeti belirlemek amacıyla sorulan sorular ve istatistiki sonuçları

\begin{tabular}{|c|c|c|}
\hline $\begin{array}{l}\text { Tokat Yeşilırmak kenarındaki rekreasyonel alanlarda kullanılan } \\
\text { donatı elamanlarına ait sorular }\end{array}$ & \multicolumn{2}{|c|}{ istatistik sonuçları } \\
\hline & S.S. & Ort. \\
\hline 1. Yeşilırmak kenarında yürüyüş yolu yeterlidir. & 1,23 & 0,85 \\
\hline 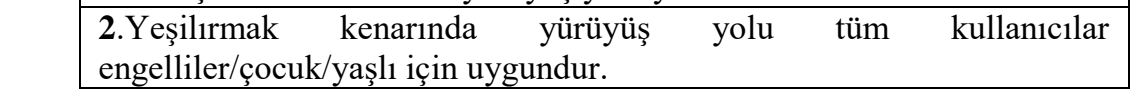 & 1,09 & 0,62 \\
\hline 3. Yeşilırmak kenarındaki yeşil alanı sınırlayan elemanlar yeterlidir & 1,07 & 0,30 \\
\hline 4. Yesilırmak kenarında cardak ve örtü elemanı yeterlidir. & 1,08 & 0,47 \\
\hline 5.Yeşilırmak kenarında aydınlatma elemanı yeterlidir. & 1,52 & 0,78 \\
\hline $\begin{array}{l}\text { 6. Yeşilırmak kenarında gölgeleme elemanı (bitki fonksiyonu ele } \\
\text { alınarak) yeterlidir. }\end{array}$ & 1,12 & 0,83 \\
\hline 7. Yeşilırmak kenarında zemin kaplaması yöre için uygundur. & 1,08 & 0,61 \\
\hline 8. Yeşilırmak kenarında plastik nesneler mevcuttur. & 1,02 & 0,46 \\
\hline 9. Yessilırmak kenarında yeterli sayıda cöp kutusu mevcuttur. & 1,21 & 0,63 \\
\hline 10. Yeşilırmak kenarında su öğesine yer verilmiştir. & 1,14 & 0,82 \\
\hline 11. Yeşilırmak kenarında hareketli su öğesi mevcuttur. & 1,15 & 0,91 \\
\hline 12. Yesilırmak'ta yüzdürülen sandal sayısı yeterlidir. & 1,23 & 0,37 \\
\hline 13. Yeşilırmak kenarında güvenlik birimi mevcuttur. & 1,14 & $-0,21$ \\
\hline $\begin{array}{l}\text { 14. Yeşilırmak kenarında malzemelerin ölçütleri tüm kullanıcılar } \\
\text { engelliler/çocuk/yaşlı için uygundur. }\end{array}$ & 1,13 & 0,39 \\
\hline 15. Kullanılan donatı elemanları konforludur. & 1,12 & 0,31 \\
\hline 16. Yesilırmak kenarında isaret levhaları yeterlidir. & 1,09 & 0,21 \\
\hline 17. Yeşilırmak kenarında yürüyüs yolları ölçütleri uygundur. & 1,18 & 0,65 \\
\hline $\begin{array}{l}\text { 18. Yeşilırmak kenarında kışın karlanma ve buzlanmada rampalarda } \\
\text { korkuluk mevcuttur. }\end{array}$ & 1,04 & 0,31 \\
\hline 19. Banklar yeterlidir. & 1.02 & 0,54 \\
\hline 20. Donatı elemanları genel olarak estetiktir. & 1,12 & 0,74 \\
\hline
\end{tabular}

Yapılan anket sonucunda 11. Soruya 'Yeşilırmak kenarında hareketli su öğesi mevcuttur' görüşü, 0,91 değeri ile en yüksek sonuca ulaşmıştır. Bu sonuç, alanın Yeşilırmak kenarında olması faktörü ile örtüşen bir sonuçtur (Tablo 1). 12. Soruda 'Yeşilırmak'ta yüzdürülen sandal sayısı yeterlidir' görüşüne katılanların ortalaması 0,37 (düşük)'dir. 13. soruda iseYeşilırmak kenarında güvenlik birimi mevcuttur. $-0,21$ (çok düşük) değer almıştır. 14. Soruda ise 'Yeşilırmak kenarında malzemelerin ölçütleri tüm kullanıcılar engelliler/çocuk/yaşı için uygundur' görüşüne katılanların ortalaması 0,39 (düşük)'dur. 15. soruda 'Kullanılan donatı elemanları konforludur' kanısına katılanların ortalaması 0,31(düşük)'dir. $\mathrm{Bu}$ sonuçlara göre kullanıcılar, donatı elamanı olarak alanda güvenlik biriminin yetersiz olduğunu, malzeme ölçütlerinin istenilen konforu ve ölçütleri sağlamadığını düşünmektedirler. 


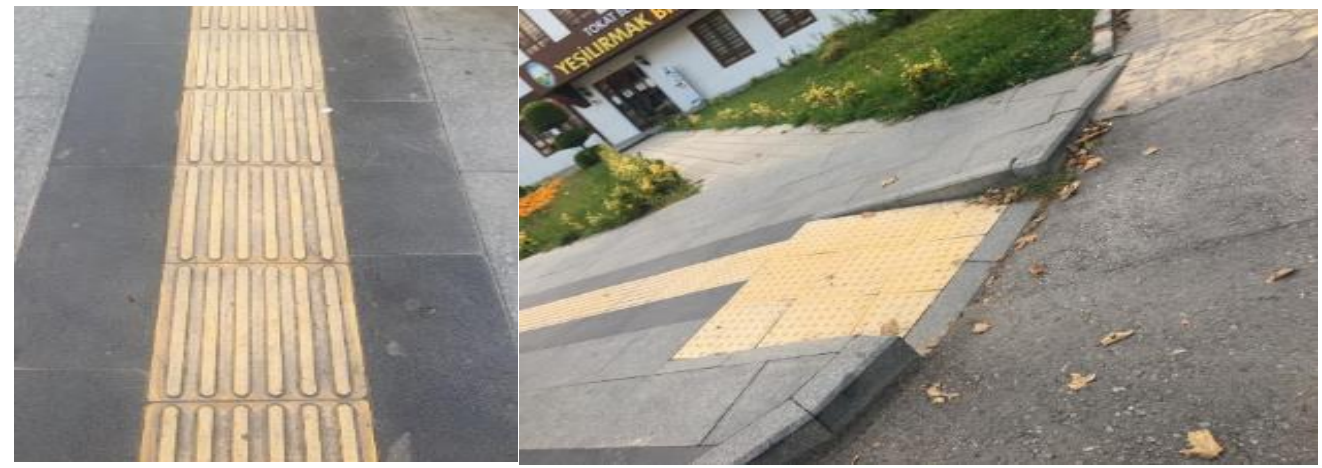

Şekil 4. Görme engelliler için rampa ve yürüme yolu (Özgün)

16. soruya verilen yanıta göre 'Yeşilırmak kenarında işaret levhaları yeterlidir' 0,21 ile ortalaması düşük bir değere sahiptir. 17. Soruda ise, 'Yeşilırmak kenarında yürüyüş yolları ölçütleri uygundur' görüşüne katılma oran 0,65 olarak ortalamanın üstünde bir değerde çıkmıştır. 18. Soruda ise; 'Yeşilırmak kenarında kışın karlanma ve buzlanmada rampalarda korkuluk mevcuttur' görüşü, 0,31 gibi ortalaması düşük bir değere sahiptir. 19. Soruda kullanıcılar bankları yeterli $(0,54)$ bulmamışlardır. 20. Soruda ise ' Donatı elemanları genel olarak estetiktir' görüşüne katılım 0,74 olarak tespit edilmiştir. Elde edilen sonuçlara göre kullanıcılar, donatı elamanlarını estetik bulmalarına rağmen ölçüt ve konfor bakımından uygun bulmamışlardır. Rampa ve korkulukları da mevsimsel olarak eksik bulmaktadırlar.

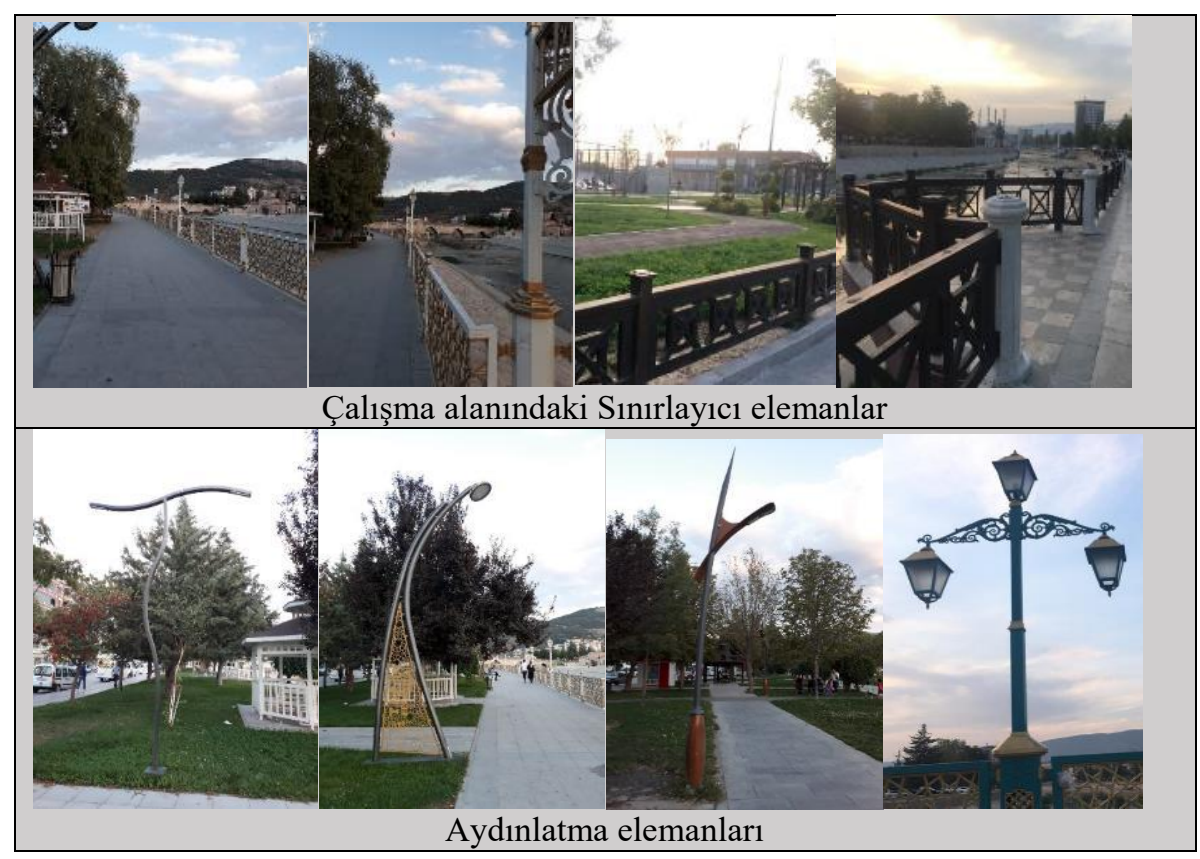

Şekil 5.Sınırlayıcı elemanlar, aydınlatma elemanlarına ait görüntüler 
ISPEC Tarım Bilimleri Dergisi

2020 : 4(3)

(C) Telif hakk ISPEC'e aittir

Arastırma Makalesi
E-ISSN:2717-7238

:

www.ispecjournal.com
ISPEC Journal of Agr. Sciences

$2020: 4(3)$

Copyright (C) ISPEC

$\underline{\text { Research Article }}$

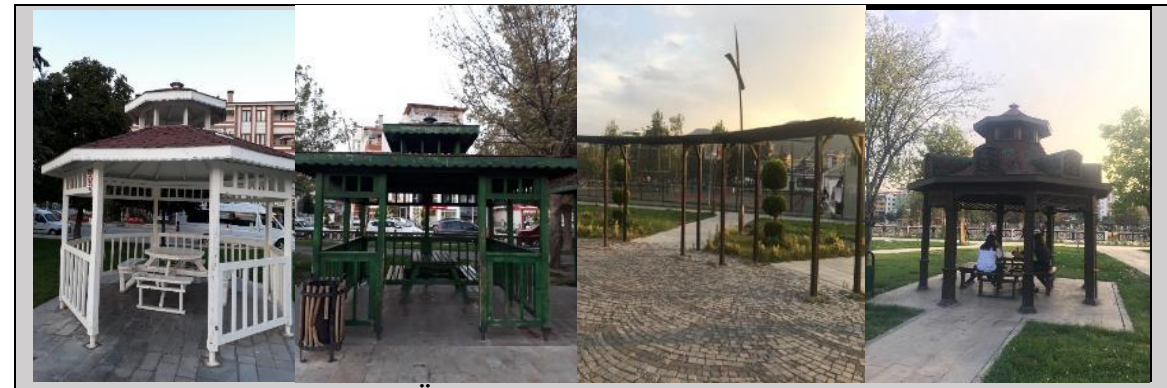

Üstü kapalı oturma alanları

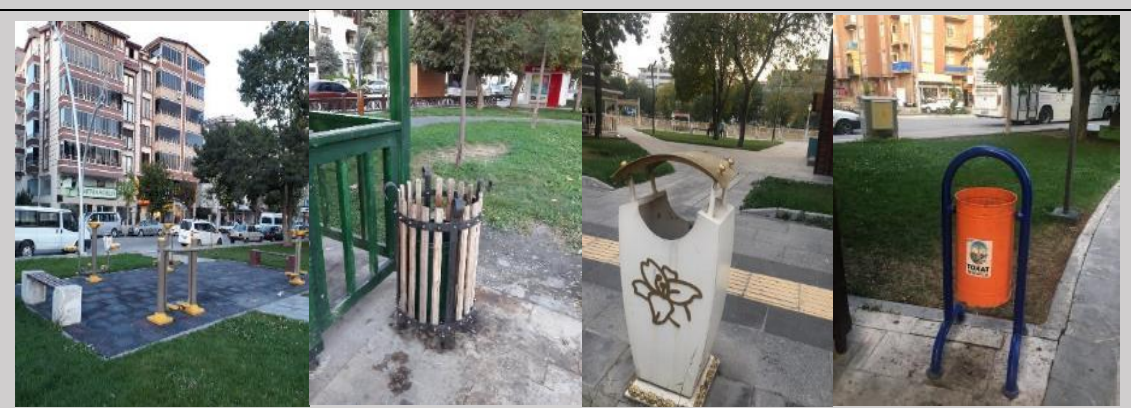

Spor aletleri ve çöp kutusu

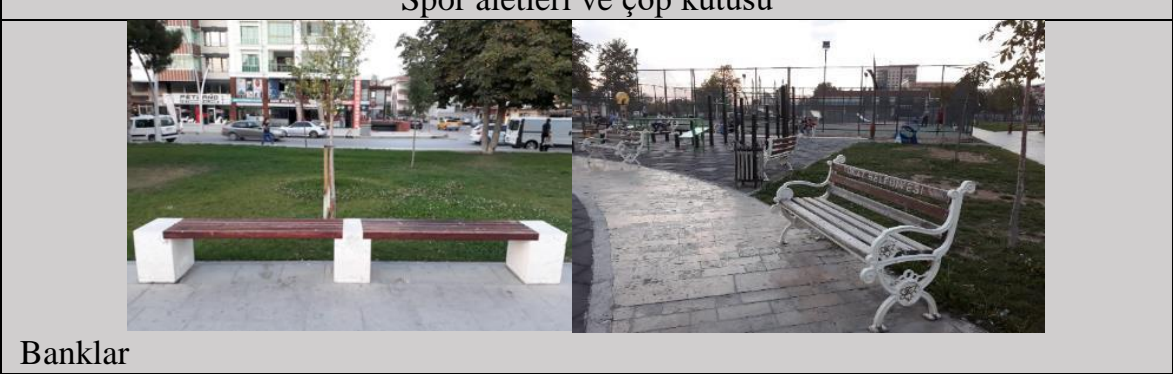

Şekil 6.Üstü kapalı oturma alanları, spor aletleri ve çöp kutusu ve banklara ait görüntüler

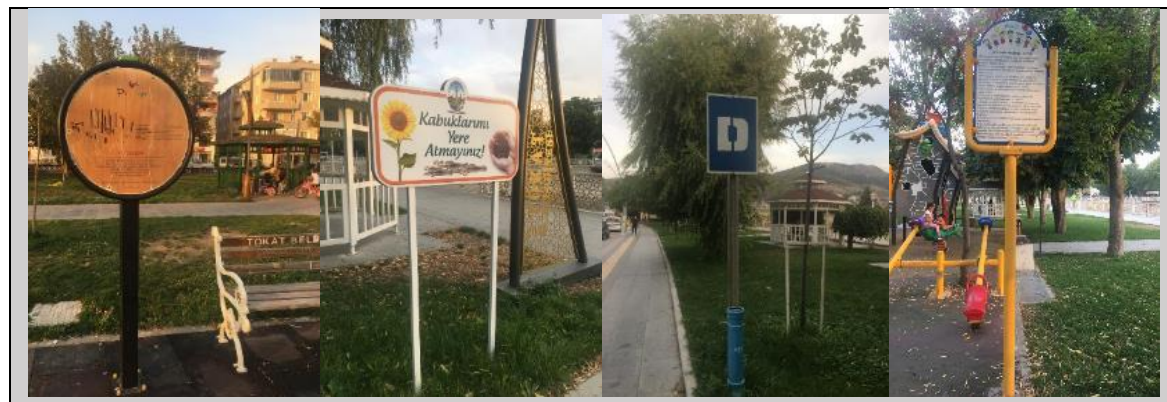

Levha ve işaretler

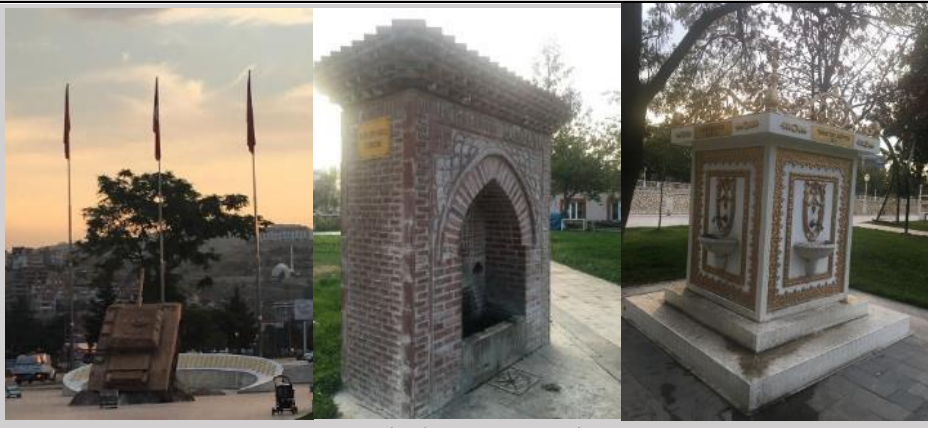

Heykel ve Ceşmeler 
Şekil 7. Levha ve işaretler, heykel ve çeşmelere ait görüntüler

\section{TARTIŞMA-SONUÇ}

Nüfusun artmasıyla orantılı olarak kentlerde donatı elemanı ihtiyacı da artmaktadır. Artan nüfusun gereksinimlerini karşılamak için plansız ve ölçüsüz yapılan donatı elamanlarının bir de kötü kullanımı ve tahribatı ile kentlerde olumsuz görüntüler meydana gelebilmektedir. Tasarımdan yoksun, ergonomik olmayan donatı elemanları, kent kimliğini olumsuz yönde etkileyen bir unsur olarak ortaya çıkmaktadır. Bu çalışma ile Tokat kentinde en yoğun şekilde tercih edilen ırmak kenarındaki rekreasyonel alanlarda donatı elemanı kullanımı incelenmiştir. Anket yoluyla elde edilen kullanıcı memnuniyeti sonuçlarına ek olarak bu bölümde uzman değerlendirmesi ve farklı çalışmaların sonuçları ile bu çalışma değerlendirilmiştir. Yapılan anket sonucunda elde edilen veri analizleri göz önünde bulundurulduğunda; kullanıcılar, yürüyüş yollarını yeterli bulmuşken sinırlayıcı elemanları yeterli bulmamışlardır. Bayramoğlu ve Özdemir (2012); Yücel (2006)'e göre sinırlayıcı elemanların kullanıldığ 1 ortamda estetik açıdan mimariye de uyum sağlanmalıdır. Kuşatma elemanı kalitesi ve derecesi çevreye uygun olmalıdır. $\mathrm{Bu}$ açıdan Yeşilırmak kenarında kullanılan sınırlayıcı elemanlar kalitelidir. Ancak kullanılan malzeme, kayıkların bulunduğu iskelede ve kafeteryaların olduğu alanlarda eksik kalmıştır. Bunun yanı sıra sınırlayıcı elemanların çeşitliliği az olup tek amaçla, sadece Irmak ile park güvenliğini sağlamak amacıyla kullanılmıştır. Ayrıca çardak ve üstü örtülü elemanların yetersiz olduğu da çıkan sonuçlar arasındadır. $\mathrm{Bu}$ sonuçlara göre tabloda da görüldüğü gibi; aydınlatma elemanları, alandaki bitkilerin gölgeleme fonksiyonu ve su öğesi kullanımı ile ilgili maddeler, ortalamanın üstünde puan almıştır. Yenioğlu (2010) , yaptığ çalışmada aydınlatma elemanlarının uygun görüş sağlama güvenliğini artırma açısından önemli olduğunu, ayrıca gündüzleri dikkat çekmeyen aydınlatma elemanlarının gece kullanıldığ1 ortama estetik bir değer kattığını bildirmiştir. Altındağ Parkı'nda yapılan bu çalışmada bitkilerin aydınlatma tasarımının eksik olduğu ortaya çıkmıştır. Bu çalışmada da farklı aydınlatma elemanlarına yer verilmesine rağmen bitkilerin aydınlatılmasında eksiklikler dikkat çekmektedir. Yine tabloda görülmektedir 
ki, kullanıcılar, aydınlatma elemanları, alandaki bitkilerin gölgeleme fonksiyonu ve su öğelerinden memnun iken çöp kutusu kullanımı, ortalama değer skalasında kalmıştır. Kartay ve Korkut (2009) , yaptıkları çalışmada, İstanbul örneğinde donatı elemanlarının antropometri ilişkisini incelemişlerdir. Çalışmada, çöp kutularının $(60-100 \mathrm{~cm}) \quad$ ortalamasında olduğu belirtilmiştir. Bu çalışmada da çöp kutuları standartlarda olmakla birlikte yeterlilik bakımından kullanıcıların kararsız kaldıkları ortaya çıkmıştır. Yücel (2006), çalışmasında, çöp kutularının gecede kullanımının göz önünde bulundurularak, boşaltılma sıklıkları yer seçim kararlarını ve tasarımlarını etkileyen bir faktör olduğunu belirtmiştir. Verilerden elde edilen çizelge sonuçlarına da bakıldığında anlaşılıyor ki, çalışma alanı kısmen uygun şartlar sağlamasına rağmen eksiklikler de mevcuttur. Yeşilırmak kenarında üç büfe mevcuttur. Bu büfelerin biri durak önünde diğer ikisi ise park ile anayol kaldırımı arasındadır. Erkmen ve Bakırküre (1991) yaptıkları çalışmada, büfelerin, kaldırım genişliği göz önüne alınarak uygun yerlere yerleştirilmesi gerekliliğini vurgulamışlardır. Donatı elemanları, kullanıcıların konforu için önemliyken kentsel alanlarda da kent kimliği için (kentin vitrini olarak) önemli yere sahiptir. İnsanların birbiri ile iletişime geçtiği kentsel alanlarda, donatı elemanları da kent kültürüne uyumlu olmalıdır. Bu çalışmada elde edilen veriler 1şı̆̆ında; kent kimliğine uygun olabilecek malzemelerin kullanıldığ 1 donatı elemanlarında konfor eksikliği olduğu, konforlu olan donatı elemanlarının da ya mevcut sayısının yetersiz ya da estetik yönden (kötü veya bakımsız) uyumsuz olduğu saptanmıştır. Ortaya çıkan bu sonuçlar doğrultusunda, donatı elemanlarının tercihinde, tasarım, kullanılan malzeme ve ergonomik özellikler (TSE standartlarına göre) konularının önemli olduğu ortaya çıkmıştır.

\section{TEŞEKKÜR}

$\mathrm{Bu}$ çalışmaya katkı sağlayan ve bizi destekleyen Doç. Dr. Kübra YAZİCI'ya teşekkür ederiz.

\section{KAYNAKLAR}

Akça, Ş. B., Gülgün, B., Yazici, K., 2018. Kentsel peyzajda çocuk oyun alanlarının bitkisel tasarım kriterleri. Presented At The Uluslararası Kentleşme Ve Çevre Sorunları Sempozyumu: Değişim/Dönüşüm/Özgünlük, Eskişehir.

Akça, Ş. B., Gülgün, B., Yazici, K. 2019. Çaycuma ilçesi park ve çocuk oyun alanlarındaki süs bitkilerinin kullanımı. 
Presented at the Uluslararası Göbeklitepe Tarım Kongresi, Şanlıurfa.

Aksu, A., Y1lmaz, H. 2018. Atatürk Üniversitesi merkezi açık-yeşil alandaki fiziki değişim memnuniyetinin belirlenmesi. Iğdır Üniversitesi Fen Bilimleri Enstitüsü Dergisi, 8(2): 231-237.

Bayramoğlu, E., Özdemir, B. 2012. Trabzon kent merkezi, uzun sokak kentsel donatı elemanlarının kent kimliği açısından değerlendirilmesi. Kastamonu University Journal of Forestry Faculty, 12(2):182-191.

Bayraktar, N., Tekel, A., Yalçıner Ercoşkun, Ö. 2013. Ankara Atatürk bulvarı üzerinde yer alan kentsel donatı elemanlarının sinıflandirılması,

Değerlendirilmesi Ve Kent Kimliği İlişkisi .Gazi Üniversitesi Mühendislik Mimarlık Fakültesi Dergisi, 23 (1)

Bulut, Y., Atabeyoğlu, Ö., Yeşil, P. 2008. Erzurum kent merkezi donatı elemanlarının ergonomik özelliklerinin değerlendirilmesi üzerine bir araştırma. Ankara Üniversitesi Ziraat Fakültesi Tarım Bilimleri Dergisi, 14(2): 131-138.

Çubuk, M. 1991. Kamu mekanları ve kentsel tasarım. kamu mekanları tasarımı ve kant mobilyaları sempozyumu. Mimar Sinan Üniversitesi Mimarlık Fakültesi, 1517, İstanbul.
Düzenli, T.T., Eren, E. Alpak, E. M. 2017. Müze bahçelerinin peyzaj özellikleriyle kullanıcı memnuniyeti ilişkisi. International Periodical for the Languages, Literature and History of Turkish or Turkic., 12(13): 201-214.

Erkmen, K., Bakırküre, G. 1991. Ankara'nın Kimliğine Katkı: Şehir Mobilyaları", Arredemento Dekorasyon, S.28,188-190,1991.

Gülgün, B., Akça, Ş. B., Aşur, F. 2018. Examination Of Landscape Equipment Elements In Terms Of Ergonomic And Anthropometric Zonguldak Bulent Ecevit University Farabi Campus Example. Presented At The Uluslararası Kentleşme Ve Çevre Sorunları Sempozyumu: Değişim/Dönüşüm/Özgünlük, Eskişehir.

Gülgün, B., Güney, M. A., Aktaş, E. Yazici, K. 2014. Role of landscape architect in interdisciplinary planing of sustainable cities. Journal Of Environmental Protection and Ecology, 15(4), 1877-1880.

Gülgün, B., Türkyılmaz, B. 2001a. Peyzaj mimarlığında antropometri ve Bornova örneğinde bir araştırma. Ege Üni. Ziraat Fak. Derg., 38(2-3), 135-142.

Gülgün, B., ve Türkyılmaz, B. 2001 b. Peyzaj mimarlığında ve insan yaşamında ergonominin yeri-önemi ve Bornova 
örneğinde bir araştırma. Ege Üni. Ziraat Fak. Derg., 38(2-3): 127-134.

Gülgün, B., Yazici, K., Keskin, N. 2018. Being handicapped İn Turkey environmental and landscape architecture. Presented at the 8th International Conference of Ecosystems.

Gülgün, B., Yazici, K. 2017. The Role and Importance of Landscape Architecture Preventing Visual pollution For A Habitable Environment The Example Of İzmir. Presented at the 7th International Conference of Ecosystem.

Gülgün, B., Yazici, K. 2018. Effects of minimalism and the far east concept on landscape designing. Presented at the 8th International Conference of Ecosystems.

Güneş, A., Gülgün, B., Yörük, İ. 2005. Sürdürülebilir kentler ve peyzaj mimarlığı. Ege Üniversitesi Ziraat Fakültesi Dergisi, 42(2): 215-226.

Güneş, A., Gülgün, B., Aktaş, E. 2011. A Dream of future sustainable cities by landscape architecture perspective. Presented At The International Conference Of Ecosystems (Ice), Tiran.

Karatay, A., Korkut A.B 2009. Peyzaj mimarlığı antropometri ilişkisi: İstanbul Örneği, Tekirdağ Ziraat Fakültesi Dergisi, 6(3) Journal of Tekirdag Agricultural Faculty.
Kuşkun, P. 2002. Erzurum kent bütününde donatı elemanlarının kullanımı üzerine bir araştırma. Atatürk Üniversitesi Fen Bilimleri Enstitüsü Yüksek Lisans Tezi, 142, Erzurum.

Önal, S. 2019. Kent parklarda kullanılan donatıların standartlara uygunluğunun belirlenmesi. Ankara Örneği. Antropoloji, 38:54-64.

Tokat Belediyesi. 2019. www.tokatbel.tr

Yazici, K., Arslantaş Sağlamer A. 2019. Tokat kenti -yeşilırmak yakın çevresinde bulunan rekreasyonel alanlarda kullanıc1 memnuniyetinin belirlenmesi. Türk Tarım ve Doğa Bilimleri Dergisi 6(4): 766-776.

Yazici, K., Gülgün Aslan, B. 2017. Açıkyeşil alanlarda dış mekân süs bitkilerinin önemi ve yaşam kalitesine etkisi; Tokat kenti örneği. Ege Üniv. Ziraat Fak. Derg., 54(3):2 75-284.

Yazici, K., Kalaycı Önaç, A. Gülgün, B. 2018. Süs bitkilerinin kampüs alanlarında işlevsel kullanımı Tokat Gaziosmanpaşa Üniversitesi örneği. Presented At The Uluslararası Marmara Fen Ve Sosyal Bilimler Kongresi 2018, Kocaeli.

Yenioğlu F. 2010. Kent parklarında aydınlatma elemanlarının kullanımının peyzaj mimarlığı açısından irdelenmesi: Ankara-Altınpark örneği, Bartın Üni., Fen Bilimleri Enstitüsü, Yüksek Lisans tezi. 
Yörük, İ., Gülgün, B., Sayman, M. Ankaya, F. Ü. 2006. Peyzaj Planlama Çalışmaları Kapsamında Ege Üniversitesi Kampüs Örneğindeki Peyzaj Donatı Elemanlarının Ergonomik Antropometrik Açıdan İrdelenmesi, Ege University Journal of Agricultural Faculty, 43(1), pp. 157-168.
Yücel, G.,F. 2006. Kamusal Açık Mekanlarda Donatı Elemanlarının Kullanımı”, Ege Mimarlık, S.4, 26-29. 